JURNAL PLANS

Penelitian Ilmu Manajemen \& Bisnis

ISSN: 1978-7057

\title{
PENGARUH FAKTOR-FAKTOR PRODUKSI TERHADAP PENDAPATAN PETANI JAGUNG DI DESA TUPAK RAJA, KECAMATAN GUNUNG SITEMBER, KABUPATEN DAIRI
}

\author{
Sandri Joito Manjorang \\ Alumni Jurusan Manajemen Fakultas Ekonomi Universitas Negeri Medan \\ Edison Sagala \\ Dosen Jurusan Manajemen Fakultas Ekonomi Universitas Negeri Medan
}

\begin{abstract}
Abstrak
Tujuan dari penelitian ini adalah untuk mengetahui pengaruh faktor - faktor produksi (Luas lahan, tenaga kerja, dan modal) terhadap pendapatan petani jagung di Desa Tupak Raja Kecamatan Gunung Sitember Kabupaten Dairi. Populasi dalam penelitian ini adalah semua petani pemilik lahan jagung di Desa Tupak Raja Kecamatan Gunung Sitember Kabupaten Dairi yang berjumlah 103 petani jagung. Teknik pengambilan sampel yang digunakan adalah random sampling sehingga diperoleh sampel sebanyak 50 responden. Analisis data pada penelitian ini diperoleh persamaan regresi $Y=0,864+0,426 X_{1}+0,142 X_{2}+0,460 X_{3}+$ e. Nilai konstanta 0,864 diasumsikan jika tidak dipengaruhi oleh faktor - faktor produksi, maka pendapatan petani tetap sebesar 0,864. Koefisien regresi luas lahan (XI) sebesar 0,426 menyatakan setiap ada peningkatan luas lahan 1 Ha akan mempengaruhi pendapatan petani sebesar 0,426. Koefisien regresi tenaga kerja (X2) sebesar 0,142 artinya apabila petani menambah 1 tenaga kerja maka akan meningkatkan pendapatan petani sebesar 0,142. Koefisien regresi modal (X3) sebesar 0,460 artinya jika modal bertambah 1 rupiah, maka akan mempengaruhi pendapatan sebesar 0,460. Koefisien Determinasi (adjust $R$ Square) sebesar 0,715 artinya bahwa besarnya pengaruh luas lahan, tenaga kerja, dan modal terhadap pendapatan petani jagung di Desa Tupak Raja Kecamatan Gunung Sitember Kabupaten Dairi sebesar 71,5\% dan sisanya 28,5\% dipengaruhi oleh variabel lain diluar penelitian. Hasil uji hipotesis dalam penelitian ini diperoleh $t_{\text {hitung }} X 1$ (3.141), $X_{2}(2.011)$, $X 3$ (4.113) dengan $p<0,05$, maka hipotesis diterima yang artinya bahwa luas lahan, tenaga kerja, dan modal berpengaruh positif dan signifikan terhadap pendapatan petani jagung di Desa Tupak Raja Kecamatan Gunung Sitember Kabupaten Dairi. Dari Uji F diperoleh $F_{\text {hitung }}>F_{\text {tabel }}(38.455>3,19)$ dengan level of significant $(\alpha) 0,000<0,005$ yang berarti bahwa variabel luas lahan, tenaga kerja, dan modal secara bersama - sama (simultan) berpengaruh terhadap pendapatan petani jagung di Desa Tupak Raja Kecamatan Gunung Sitember Kabupaten Dairi.
\end{abstract}

Kata Kunci : Luas Lahan, Tenaga Kerja, Modal, Pendapatan

\section{PENDAHULUAN}

Indonesia merupakan negara agraris, artinya sektor pertanian dalam tatanan pembangunan nasional memegang peranan penting, karena selain bertujuan menyediakan pangan bagi seluruh penduduk, pertanian juga merupakan andalan penyumbang devisa negara dari sektor non migas. Indonesia adalah negara yang sebagian besar mata pencaharian penduduknya adalah bertani. Kenyataan yang terjadi yakni sebagian besar penggunaan lahan di wilayah Indonesia diperuntukkan sebagai lahan pertanian dan hampir $50 \%$ dari total angkatan kerja masih 
menggantungkan nasibnya bekerja di sektor pertanian (Husodo, dkk, 2004:23-24).

Sektor pertanian di Indonesia sampai saat ini masih memegang peranan penting yang berdampingan dengan sektor lainnya, khususnya industri. Hal inilah yang menyebabkan pentingnya pembangunan pertanian di Indonesia. Peranan sektor pertanian bagi kehidupan masyarakat di pedesaan sangat ditentukan oleh luas lahan pertanian. Dalam hal ini lahan pertanian dalam usahatani merupakan faktor produksi utama dalam menyerap tenaga kerja dan sumber pendapatan petani, sehingga tinggi rendahnya penggunaan tenaga kerja dan pendapatan petani antara lain akan ditentukan oleh luas lahan pertanian yang dikuasai dan digarap. Penggunaan faktor-faktor produksi di dalam usaha pertanian merupakan hal yang penting, karena tanpa faktor-faktor produksi tersebut tentunya petani tidak dapat memproduksi usahatani, jika petani tidak dapat memproduksi usahatani tentu saja petani tidak akan menerima pendapatan dari usahataninya.

Keberhasilan usahatani dipengaruhi oleh faktor produksi (modal, tanah, tenaga kerja). Modal diperlukan untuk pengadaan sarana produksi (benih, pupuk, pestisida, dan peralatan), biaya pemeliharaan tanaman, biaya penyimpanan, pemasaran, dan pengangkutan. Dalam usahatani, kekurangan modal menyebabkan kurangnya masukan yang diberikan sehingga menimbulkan resiko kegagalan atau rendahnya produktivitas. Petani cenderung mengalami hambatan dalam mengembangkan hasil usahataninya dengan menambah luas lahan maupun pengadaan sarana produksi (Darmawaty, 2005:76).

Menurut Griffin, (2006:14), saat ini ada lima hal yang dianggap sebagai faktor produksi, yaitu tenaga kerja (labor), modal (capital), sumber daya fisik (physical resources), kewirausahaan (entrepreneurship), dan sumber daya informasi (information resources). Faktorfaktor produksi tersebut harus dikombinasikan oleh petani untuk memperoleh produksi atau pendapatan dalam usaha tani. Masingmasing faktor produksi tersebut mempunyai fungsi yang berbeda, namun memiliki keterkaitan satu sama lain. Jika salah satu faktor tidak tersedia, maka proses produksi tidak akan berjalan, otomatis hasil dari produksi atau pendapatan tidak akan maksimal atau bahkan dapat mengalami kerugian.

Untuk mendapatkan produksi yang tinggi, petani harus cermat dalam penggunaan faktor-faktor produksi usaha tani yang mempunyai hubungan terhadap tingkat produksi dan pendapatan yang diterima petani. Semakin luas lahan (tanah) usaha tani yang diusahakan, maka jumlah produksi yang dihasilkan juga semakin banyak sehingga pendapatan yang diterima petani semakin tinggi. Jagung (Zea mays L.) merupakan salah satu bahan pangan penting karena merupakan sumber karbohidrat penting kedua setelah beras. Di Indonesia selain sebagai bahan pangan dan bahan baku industri, jagung juga merupakan sumber pakan bagi ternak. Tanaman jagung sudah terkenal dan dibudidayakan sejak lama di Indonesia, bahkan dari 
pengembangan tanaman jagung telah menghasilkan beberapa varietas jagung unggul yang menghasilkan turunan jagung berumur panen singkat, buah besar, tongkol besar, berasa masir dan manis kalau sudah bisa direbus atau diolah menjadi berbagai macam makanan. Hal tersebut didukung selain oleh lingkungan sebagai syarat tumbuh tanaman jagung memungkinkan tumbuh subur, juga lantaran pemeliharaan sampai reproduksi tanaman jagung relatif mudah dan sederhana. Tinggal lagi bagaimana perlakuan budidaya yang akan berimbas terhadap kuantitas dan kualitas produksi tanaman jagung. Penggunaan jagung sebagai bahan pangan dan pakan terus mengalami peningkatan. Sementara ketersediaannya terbatas, untuk itu perlu dilakukan upaya peningkatan produksi melalui perluasan lahan, penanaman dan peningkatan produktivitas. Dari sisi pasar, potensi pemasaran jagung terus mengalami peningkatan. Hal ini dapat dilihat dari semakin berkembangnya industri peternakan yang pada akhirnya akan meningkatkan permintaan jagung tua sebagai campuran pakan ternak.

Kecamatan Gunung Sitember merupakan salah satu penyumbang produksi jagung terbesar di Kabupaten Dairi, disamping Kecamatan Tanah Pinem dan Tigalingga. Tupak Raja adalah sebuah desa yang terdapat di Kecamatan Gunung Sitember, Kabupaten Dairi. Desa Tupak Raja memiliki luas 6 $\mathrm{Km}^{2}$. Data yang diperoleh MedanBisnis dari Dinas Pertanian Kabupaten Dairi, luas lahan serta jumlah produksi jagung petani di 15 Kecamatan di Kabupaten tersebut mengalami peningkatan dalam per tahunnya. Sehingga produksi jagung yang dihasilkan petani sangat memadai untuk mendirikan perusahaan pengolahan biji jagung tersebut. Untuk lebih jelasnya berikut tampilan data perkembangan luas panen jagung dan perkembangan produksi jagung berdasarkan Kecamatan di Kabupaten Dairi.

Tabel 1. Perkembangan Luas Panen Jagung Berdasarkan Kecamatan di Kabupaten Dairi, Tahun 2010 - 2011

\begin{tabular}{|c|c|c|c|}
\hline No. & Kecamatan & \multicolumn{2}{|c|}{ Luas Panen (Ha) } \\
\hline & & 2010 & 2011 \\
\hline 1 & Sidikalang & 813 & 822 \\
\hline 2 & Sitinjo & 367 & 799 \\
\hline 3 & Berampu & 790 & 371 \\
\hline 4 & Parbuluan & 2,467 & 1,495 \\
\hline 5 & Sumbul & 943 & 954 \\
\hline 6 & Silahisabungan & 37 & 37 \\
\hline 7 & $\begin{array}{l}\text { Silima Pungga - } \\
\text { pungga }\end{array}$ & 1,605 & 1,623 \\
\hline 8 & Lae Parira & 680 & 688 \\
\hline 9 & Siempat Nempu & 1,897 & 1,919 \\
\hline 10 & $\begin{array}{l}\text { Siempat Nempu } \\
\text { Hulu }\end{array}$ & 2,520 & 2,549 \\
\hline 11 & $\begin{array}{l}\text { Siempat Nempu } \\
\text { Hilir }\end{array}$ & 1.402 & 1,418 \\
\hline 12 & Tigalingga & 5,610 & 6,175 \\
\hline 13 & $\begin{array}{l}\text { Gunung } \\
\text { Sitember }\end{array}$ & 3,704 & 3,747 \\
\hline 14 & Pegagan Hilir & 720 & 728 \\
\hline 15 & Tanah Pinem & 9,050 & 9,654 \\
\hline & Dairi & 32,605 & 32,979 \\
\hline
\end{tabular}

Sumber : Kabupaten Dairi dalam Angka Tahun 2012. 
JURNAL PLANS

Penelitian Ilmu Manajemen \& Bisnis

ISSN: 1978-7057

Tabel 2. Perkembangan Produksi Jagung Berdasarkan Kecamatan di Kabupaten Dairi, Tahun 2010 - 2011

\begin{tabular}{|c|c|c|c|}
\hline \multirow[t]{2}{*}{ No. } & \multirow[t]{2}{*}{ Kecamatan } & \multicolumn{2}{|c|}{ Produksi (Ton) } \\
\hline & & 2010 & 2011 \\
\hline 1 & Sidikalang & 3,642 & 3,822 \\
\hline 2 & Sitinjo & 5,539 & 3,715 \\
\hline 3 & Berampu & 5,539 & 1,725 \\
\hline 4 & Parbuluan & 11,052 & 6,951 \\
\hline 5 & Sumbul & 4,235 & 4,436 \\
\hline 6 & Silahisabungan & 166 & 172 \\
\hline 7 & $\begin{array}{l}\text { Silima Pungga } \\
\text { - pungga }\end{array}$ & 7,190 & 7,546 \\
\hline 8 & Lae Parira & 3,046 & 3,198 \\
\hline 9 & $\begin{array}{l}\text { Siempat } \\
\text { Nempu }\end{array}$ & 8,499 & 8,923 \\
\hline 10 & $\begin{array}{l}\text { Siempat } \\
\text { Nempu Hulu }\end{array}$ & 11,290 & 11,852 \\
\hline 11 & $\begin{array}{l}\text { Siempat } \\
\text { Nempu Hilir }\end{array}$ & 6,281 & 6,593 \\
\hline 12 & Tigalingga & 25,133 & 28,713 \\
\hline 13 & $\begin{array}{l}\text { Gunung } \\
\text { Sitember }\end{array}$ & 16,594 & 17,423 \\
\hline 14 & Pegagan Hilir & 3,266 & 3,385 \\
\hline 15 & Tanah Pinem & 60,979 & 65,865 \\
\hline & Dairi & 172,411 & 174,319 \\
\hline
\end{tabular}

Sumber : Kabupaten Dairi dalam Angka Tahun 2012

Dari tabel di atas dijelaskan bahwa Kecamatan Gunung Sitember merupakan kecamatan dengan luas panen dan perkembangan produksi jagung yang layak untuk ditingkatkan. Seperti data yang diperoleh MedanBisnis dari Dinas Pertanian Kabupaten Dairi, hasil produktivitas jagung di Kabupaten Dairi pada tahun 2010 - 2011 antara lain dalam tabel berikut :
Tabel 3. Luas Lahan dan Produktivitas Jagung di Kabupaten Dairi Tahun 2010 - 2011

\begin{tabular}{|c|c|c|}
\hline Tahun & $\begin{array}{c}\text { Luas } \\
\text { Lahan } \\
\text { (Ha) }\end{array}$ & $\begin{array}{c}\text { Produktivitas } \\
\text { (Ton) }\end{array}$ \\
\hline 2010 & $34.161,00$ & $148.070,00$ \\
\hline 2011 & $35.084,00$ & $153.335,00$ \\
\hline
\end{tabular}

Sumber : Medan Bisnis dari Dinas Pertanian Kabupaten Dairi

Berdasarkan data yang diperoleh, Kabupaten Dairi mengalami peningkatan dalam produksi jagung. Pendapatan utama masyarakat di Desa Tupak Raja Kecamatan Gunung Sitember berasal dari usahatani jagung. Oleh karena itu masyarakat di Desa Tupak Raja harus dapat meningkatkan faktor produksi agar produksi usahataninya dapat meningkat, dengan meningkatnya produksi tentu pendapatan petani jagung di Desa Tupak Raja pun akan meningkat.

\section{METODE PENELITIAN}

\section{Lokasi Penelitian}

Lokasi penelitian ini dilakukan di Desa Tupak Raja, Kecamatan Gunung Sitember, Kabupaten Dairi.

\section{Populasi dan Sampel}

Menurut Sugiyono (2008:115) "Populasi adalah wilayah generalisasi yang terdiri dari subjek atau objek yang mempunyai kualitas atau karakteristik tertentu yang ditetapkan oleh peneliti yang dipelajari dan kemudian ditarik kesimpulan".

Tidak seluruh populasi tersebut yang akan diteliti, namun hanya akan mengambil sampel yang dianggap representatif. Populasi yang digunakan dalam penelitian ini adalah 
ISSN: 1978-7057

semua petani jagung yang ada di Desa Tupak Raja, Kecamatan Gunung Sitember, Kabupaten Dairi yang berjumlah 103 petani jagung.

Sampel adalah sebagian objek dari populasi yang dipandang dapat mewakili populasi yang dijadikan sumber informasi dalam suatu penelitian ilmiah.

Teknik pengambilan sampel yang dipakai dalam penelitian ini adalah teknik probabilitas dengan cara random sampling (Metode Sampel Acak Sederhana), yaitu dengan metode pemilihan sampel di mana setiap anggota populasi mempunyai peluang yang sama untuk dipilih menjadi anggota sampel tanpa memperhatikan strata yang ada dalam populasi dan anggota populasi dianggap homogeny. Untuk menentukan ukuran sampel ditentukan dengan menggunakan rumus Slovin sebagai berikut :

$$
n=\frac{N}{N \cdot d^{2}+1} \text { (Riduwan, 2007:65) }
$$

Ket :

$n \quad=$ jumlah sampel

$N \quad=$ jumlah populasi

$d \quad=$ presisi yang ditetapkan 10 $\%$

Berdasarkan rumus diatas diperoleh jumlah sampel, yaitu :

$n=\frac{103}{103.0,1^{2}+1}=\frac{103}{2.03}=50,73$

Sesuai dengan pengertian di atas, maka penulis menentukan sampel daa penelitian ini sebanyak 50 orang petani jagung.

Sumber data yang dikumpulkan terdiri dari data primer. Data primer diperoleh secara langsung dari petani melalui observasi, wawancara dan kuesioner.

\section{Variabel Penelitian dan Defenisi Operasional Variabel Penelitian}

a. Variabel Bebas (X) : Yaitu faktor-faktor produksi yang mempengaruhi pendapatan petani jagung yaitu lahan, tenaga kerja, dan modal.

b. Variabel Terikat (Y) :

Pendapatan petani jagung.

\section{Defenisi Operasional}

a. Faktor Produksi

Semuanya korbanan / input yang digunakan untuk melakukan suatu proses produksi untuk menghasilkan suatu output (hasil/produksi). Adapun indikator faktor-faktor produksi adalah :

1. Lahan $\left(\mathrm{X}_{1}\right)$ adalah areal tanah yang digunakan petani dalam mengelola usaha tani jagung yang dinyatakan dalam (Ha). Adapun indikator Lahan dalam penelitian ini yaitu :

- Luas Lahan

- Kesuburan Lahan

2. Tenaga Kerja $\left(\mathrm{X}_{2}\right)$ adalah orang-orang yang dipekerjakan untuk mengelola usaha tani jagung. Indikator tenaga kerja yaitu :

- Jumlah Tenaga Kerja

- Usia Tenaga Kerja

3. Modal $\left(\mathrm{X}_{3}\right)$ adalah sejumlah dana yang digunakan petani untuk mengelola usaha tani jagung yang dinyatakan dalam rupiah.

4. Pendapatan (Y) adalah total penghasilan yang diperoleh petani dari usaha tani jagung setelah dikurangi total biaya yang dikeluarkan.

Adapun indikator pendapatan adalah : 
- Jumlah Produksi, yaitu seluruh hasil produksi usaha tani jagung.

- Harga Jual, yaitu besarnya nilai penjualan dari komoditi jagung.

\section{Analisis Regresi Berganda}

Analisa regresi berganda untuk mengetahui pengaruh antara variabel bebas (Lahan, Tenaga Kerja, Modal) dan variabel terikat (Pendapatan). Analisis data dalam penelitian ini menggunakan analisis regresi yang bertujuan untuk mengetahui besarnya pengaruh beberapa variabel independen terhadap variabel dependen. Dalam penelitian ini analisis regresi yang dipakai adalah analisis regresi berganda di mana secara umum data hasil pengamatan $\mathrm{Y}$ dipengaruhi oleh beberapa variabel bebas $\mathrm{X} 1, \mathrm{X} 2, \mathrm{X} 3$, ...., Xn.

Sehingga rumus umum dari regresi berganda yaitu :

$$
\mathbf{Y}=\mathbf{a}+\mathbf{b}_{1} \mathbf{X}_{1}+\mathbf{b}_{2} \mathbf{X}_{2}+\mathbf{b}_{3} \mathbf{X}_{3}+e
$$

Dimana :

$$
\begin{array}{ll}
\mathrm{Y} & =\text { Pendapatan Petani Jagung } \\
\mathrm{a} & =\text { Konstanta } \\
\mathrm{b} & =\text { Koefisien regresi } \\
\mathrm{X}_{1} & =\text { Lahan } \\
\mathrm{X}_{2} & =\text { Tenaga Kerja } \\
\mathrm{X}_{3} & =\text { Modal } \\
\mathrm{e} & =\text { Koefisien lain }
\end{array}
$$

\section{Uji Hipotesis}

\section{a. Uji f (Uji Signifikan Simultan)}

Uji f dilakukan untuk menguji apakah semua variabel bebas $\left(\mathrm{X}_{1}, \mathrm{X}_{2}\right.$, $\mathrm{X}_{3}$ ) mempunyai pengaruh yang signifikan terhadap variabel terikat (Y) secara serentak. Cara yang digunakan adalah dengan membandingkan nilai $\mathrm{F}$ tabel dengan $\mathrm{F}$ hitung, apabila nilai $\mathrm{F}$ hitung $>\mathrm{F}$ tabel maka $\mathrm{H}_{0}$ diterima, sehingga dapat dikatakan bahwa variabel bebas dari model regresi dapat menerangkan variabel terikat secara serentak. Sebaliknya, jika $F$ hitung $<\mathrm{F}_{\text {tabel }}$ maka $\mathrm{H}_{0}$ ditolak, dengan demikian dapat dikatakan bahwa variabel bebas dari model regresi linier berganda tidak mampu menjelaskan variabel berikutnya. Untuk mengetahui signifikan atau tidak berpengaruh secara bersama-sama variabel bebas terhadap variabel terikat maka digunakan probability sebesar $5 \%(\alpha$ $=0,05$ ).

\section{b. Uji t (Parsial)}

Uji t dilakukan untuk menguji setiap variabel bebas $\left(\begin{array}{llll}\mathrm{X}_{1} & \mathrm{X}_{2} & \mathrm{X}_{3}\end{array}\right)$ apakah mempunyai pengaruh yang signifikan terhadap variabel terikat (Y) secara individu (parsial).

Langkah - langkah pengujian untuk Uji t adalah sebagai berikut :

1. Menentukan model hipotesis untuk $\mathrm{H}_{0}$ dan $\mathrm{H}_{\mathrm{a}}$.

2. $\mathrm{H}_{0}: \mathrm{b}_{1}=0$, artinya secara parsial tidak terdapat pengaruh yang positif dan signifikan dari variabel bebas (X) terhadap variabel terikat $(\mathrm{Y})$. Sedangkan jika $\mathrm{H}_{\mathrm{a}}: \mathrm{b}_{1} \neq 0$, artinya secara parsial terdapat pengaruh positif dan signifikan dari variabel bebas (X) terhadap variabel terikat (Y).

3. Mencari nilai $t$ tabel dengan cara menentukan tingkat kesalahan dan derajat kebebasan. Tingkat kesalahan yang dipakai adalah alpha 5\% dan derajat kebebasan (df) = $\mathrm{n}-\mathrm{k}$, dimana jumlah $\mathrm{n}$ adalah jumlah variabel independent yang digunakan. 
4. Menentukan kriteria pengambilan keputusan.

a. $\mathrm{H}_{0}$ diterima jika $\mathrm{t}_{\text {hitung }}<\mathrm{t}$ tabel pada $\alpha=5 \%$

b. $\mathrm{H}_{\mathrm{a}}$ diterima jika $\mathrm{t}$ hitung $>\mathrm{t}$ tabel pada $\alpha=5 \%$

5. Mencari nilai $t$ hitung dengan menggunakan

bantuan aplikasi SPSS 20.00 for windows.

\section{Identifikasi Koefisien Determinan} (R2)

Identifikasi Koefisien Determinan $\left(\mathrm{R}^{2}\right)$ digunakan untuk mengukur besarnya kontribusi persentase sumbangan variabel Lahan, Tenaga Kerja, dan Modal terhadap variabel terikat Pendapatan petani secara bersama-sama dimana 0 $<\mathrm{R}^{2}<1$. Hal ini berarti nilai $\mathrm{R}^{2}$ adalah 1 atau mendekati 1. Maka semakin kuat pengaruh variabel bebas terhadap variabel terikat. Sebaliknya, apabila nilai $\mathrm{R}^{2}$ mendekati nol, maka semakin lemah pengaruh variabel bebas terhadap variabel terikat.

\section{HASIL PENELITIAN \\ PEMBAHASAN \\ Hasil Penelitian \\ Analisis Regresi Berganda}

DAN

Model regresi berganda dengan 1 Variabel dependen (Y) yaitu variabel Pendapatan dan 3 variabel independen (X) yaitu variabel Luas Lahan (X1), Tenaga Kerja (X2), dan Modal (X3) sebagai berikut :

$$
\mathbf{Y}=\mathbf{a}+\mathbf{b}_{1} \mathbf{X}_{1}+\mathbf{b}_{2} \mathbf{X}_{2}+\mathbf{b}_{3} \mathbf{X}_{3}+\mathbf{e}
$$

Untuk menguji hipotesis yang menyatakan terdapat pengaruh Luas Lahan (X1), Tenaga Kerja (X2), dan Modal (X3) terhadap Pendapatan (Y) digunakan analisis regresi berganda.

Berdasarkan hasil perhitungan diperoleh hasil persamaan regresi berganda adalah sebagai berikut :
Tabel 4. Hasil Perhitungan Regresi Linear Berganda

\begin{tabular}{|c|c|c|c|c|c|}
\hline \multirow[b]{2}{*}{ Model } & \multicolumn{2}{|c|}{$\begin{array}{l}\text { Unstandardi } \\
\text { zed } \\
\text { Coefficients }\end{array}$} & \multirow{2}{*}{$\begin{array}{c}\begin{array}{c}\text { Standardiz } \\
\text { ed } \\
\text { Coefficient } \\
\text { s }\end{array} \\
\text { Beta }\end{array}$} & \multirow[b]{2}{*}{$t$} & \multirow[b]{2}{*}{ Sig } \\
\hline & B & $\begin{array}{l}\text { Std. } \\
\text { Error }\end{array}$ & & & \\
\hline \begin{tabular}{l|l}
1 & $\begin{array}{l}\text { (Consta } \\
\mathrm{nt})\end{array}$
\end{tabular} & .864 & 1.294 & & .668 & $\begin{array}{r}.50 \\
7\end{array}$ \\
\hline \begin{tabular}{|l|}
$\mathrm{x} 1$ \\
\end{tabular} & .426 & .136 & .379 & $\begin{array}{r}3.14 \\
1\end{array}$ & $\begin{array}{r}.00 \\
3\end{array}$ \\
\hline$x 2$ & .142 & .071 & .165 & $\begin{array}{r}2.01 \\
1\end{array}$ & $\begin{array}{r}.05 \\
0\end{array}$ \\
\hline$x 3$ & .460 & .112 & .484 & $\begin{array}{r}4.11 \\
3\end{array}$ & $\begin{array}{r}.00 \\
0\end{array}$ \\
\hline
\end{tabular}

Dari data hasil SPSS di atas dapat dijelaskan sebagai berikut : $Y=0,864+0,426 X_{1}+0,142 X_{2}+0,460 X_{3}+e$

- Konstanta (a) sebesar 0,864 menyatakan bahwa jika petani tidak menggunakan Luas Lahan, Tenaga Kerja, dan Modal, maka pendapatan usaha tani akan tetap sebesar 0,864.

- Koefisien regresi variabel $X_{1}$ sebesar 0,426 menyatakan bahwa setiap terjadi penambahan luas lahan akan mempengaruhi pendapatan petani sebesar 0,426.

- Koefisien regresi variabel $X_{2}$ sebesar 0,142 menyatakan bahwa setiap terjadi penambahan tenaga kerja akan mempengaruhi pendapatan petani sebesar 0,142 .

- Koefisien regresi variabel $X_{3}$ sebesar 0,460 menyatakan bahwa setiap terjadi penambahan modal sebesar satu rupiah akan mempengaruhi pendapatan petani sebesar 0,460 .

Dari uraian di atas dapat disimpulkan bahwa Luas Lahan, Tenaga Kerja, dan Modal berpengaruh positif terhadap pendapatan petani jagung. 
ISSN: 1978-7057

\section{Pengujian Hipotesis}

\section{Uji Simultan (Uji F)}

Diketahui bahwa hipotesis yang ditetapkan adalah bahwa Luas Lahan, Tenaga Kerja, dan Modal mempunyai pengaruh terhadap Pendapatan usaha tani. Untuk membuktikan hipotesis di atas, maka data yang telah diperoleh dari pengolahan SPSS diuji dengan uji $\mathrm{F}$ yaitu melihat bagaimana pengaruh variabel bebas secara bersama - sama terhadap variabel terikat. Dengan kriteria pengambilan keputusan sebagai berikut :

- Jika $\mathrm{F}_{\text {hitung }}>\mathrm{F}_{\text {tabel }}$ maka hipotesis diterima

- Jika $\mathrm{F}_{\text {hitung }}<\mathrm{F}_{\text {tabel }}$ maka hipotesis ditolak.

- Berdasarkan hasil pengujian statistik (Uji ANOVA/Uji F) dapat dilihat pada tabel berikut :

Tabel 5. Hasil Uji Perhitungan Uji F

\begin{tabular}{|l|l|r|r|r|r|r|}
\multicolumn{7}{|l|}{ ANOVA $^{\mathrm{a}}$} \\
\multicolumn{2}{|l|}{ Model } & $\begin{array}{c}\text { Sum of } \\
\text { Square } \\
\mathrm{s}\end{array}$ & $\mathrm{df}$ & $\begin{array}{c}\text { Mean } \\
\text { Squar } \\
\mathrm{e}\end{array}$ & $\mathrm{F}$ & Sig. \\
\hline \multirow{4}{*}{1} & $\begin{array}{l}\text { Regressi } \\
\text { on }\end{array}$ & $\begin{array}{r}571.60 \\
1\end{array}$ & 3 & $\begin{array}{r}190.53 \\
4\end{array}$ & $\begin{array}{r}38.4 \\
55\end{array}$ & $\begin{array}{r}.000 \\
\mathrm{~b}\end{array}$ \\
\cline { 2 - 7 } & Residual & $\begin{array}{r}227.91 \\
9\end{array}$ & 46 & 4.955 & & \\
\cline { 2 - 7 } & Total & $\begin{array}{r}799.52 \\
0\end{array}$ & 49 & & & \\
\hline
\end{tabular}

a. Dependent Variable: y

b. Predictors: (Constant), x3, x2, x1

Dari hasil pengujian terhadap uji Anova atau $F$ test seperti yang ditampilkan di atas diperoleh nilai $\mathrm{F}$ hitung sebesar 38.455 sedangkan nilai dari $\mathrm{F}_{\text {tabel }}$ yang diperoleh dengan $\mathrm{k}=$ $2, \mathrm{dk}=50-2=48$ dan taraf kesalahan 5\% adalah sebesar 3,19.

Jika dibandingkan antara $\mathrm{F}$ hitung dan $\mathrm{F}$ tabel maka dapat dilihat bahwa $\mathrm{F}_{\text {hitung }}>\mathrm{F}$ tabel $(38.455>3,19)$, dengan demikian dapat ditarik kesimpulan bahwa Luas Lahan,
Tenaga Kerja, dan Modal secara bersama - sama dapat mempengaruhi Pendapatan usaha tani jagung atau dengan kata lain hipotesis yang dirumuskan dapat diterima.

\section{Uji Parsial (Uji t)}

Uji parsial (Uji t) bertujuan untuk mengetahui besarnya pengaruh masing - masing variabel independent secara individual atau parsial terhadap variabel dependen. Kriteria pengambilan keputusan sebagai berikut :

- Jika $\mathrm{t}_{\text {hitung }}>\mathrm{t}_{\text {tabel }}$ maka hipotesis diterima

- Jika $\mathrm{t}_{\text {hitung }}<\mathrm{t}$ tabel maka hipotesis ditolak.

Tabel 6. Hasil Uji Parsia (Uji t)

Coefficients (a)

\begin{tabular}{|c|c|c|c|c|c|c|}
\hline \multirow{2}{*}{\multicolumn{2}{|c|}{ Model }} & \multicolumn{2}{|c|}{$\begin{array}{l}\text { Unstandardi } \\
\text { zed } \\
\text { Coefficients }\end{array}$} & \multirow{2}{*}{$\begin{array}{c}\begin{array}{c}\text { Standardiz } \\
\text { ed } \\
\text { Coefficient } \\
\text { s }\end{array} \\
\text { Beta }\end{array}$} & \multirow[b]{2}{*}{$t$} & \multirow[b]{2}{*}{ Sig } \\
\hline & & $\mathrm{B}$ & $\begin{array}{l}\text { Std. } \\
\text { Error }\end{array}$ & & & \\
\hline & $\begin{array}{l}\text { (Consta } \\
\text { nt) }\end{array}$ & .864 & $\begin{array}{r}1.29 \\
4 \\
\end{array}$ & & .668 & $\begin{array}{r}.50 \\
7 \\
\end{array}$ \\
\hline & $\mathrm{x} 1$ & .426 & .136 & .379 & $\begin{array}{r}3.14 \\
1 \\
\end{array}$ & $\begin{array}{r}.00 \\
3 \\
\end{array}$ \\
\hline & $x 2$ & .142 & .071 & .165 & $\begin{array}{r}2.01 \\
1\end{array}$ & $\begin{array}{r}.05 \\
0\end{array}$ \\
\hline & $x 3$ & .460 & .112 & .484 & $\begin{array}{r}4.11 \\
3 \\
\end{array}$ & $\begin{array}{r}.00 \\
0\end{array}$ \\
\hline
\end{tabular}

Berdasarkan tabel di atas diperoleh nilai $t$ hitung masing masing variabel. Untuk variabel luas lahan (X1) diperoleh nilai $\mathrm{t}_{\text {hitung }}=$ 3.141 nilai tersebut lebih besar dari nilai $\mathrm{t}$ tabel yang didapat dengan $\alpha=$ $5 \%$ dan $\mathrm{dk}=48(50-2)$ yaitu sebesar 1,677. Dengan demikian dapat disimpulkan bahwa Variabel Luas Lahan (X1) berpengaruh positif dan signifikan terhadap Pendapatan usaha tani (Y). Ini menunjukkan bahwa hipotesis yang dirumuskan dapat diterima.

Untuk variabel Tenaga Kerja (X2) diperoleh nilai $t_{\text {hitung }}=2.011$, 
ISSN: 1978-7057

nilai tersebut lebih besar dari $\mathrm{t}$ tabel yang didapat dengan $\alpha=5 \%$ dan $\mathrm{dk}=$ 48 (50-2) yaitu sebesar 1,677. Dengan demikian dapat disimpulkan bahwa Variabel Tenaga Kerja (X2) berpengaruh positif dan signifikan terhadap Pendapatan usaha tani (Y). Ini menunjukkan bahwa hipotesis yang dirumuskan dapat diterima.

Sedangkan untuk Variabel Modal (X3) diperoleh nilai $\mathrm{t}_{\text {hitung }}=$ 4.113, nilai tersebut lebih besar dari t tabel yang didapat dengan $\alpha=5 \%$ dan $\mathrm{dk}=48(50-2)$ yaitu sebesar 1,677. Dengan demikian dapat disimpulkan bahwa Variabel Modal (X3) berpengaruh positif dan signifikan terhadap Pendapatan usaha tani (Y). Ini menunjukkan bahwa hipotesis yang dirumuskan dapat diterima.

\section{Koefisien Determinan}

Determinan digunakan untuk mengetahui seberapa besar variabel independen mampu menjelaskan pengaruh variabel dependen.

Tabel 7. R Square

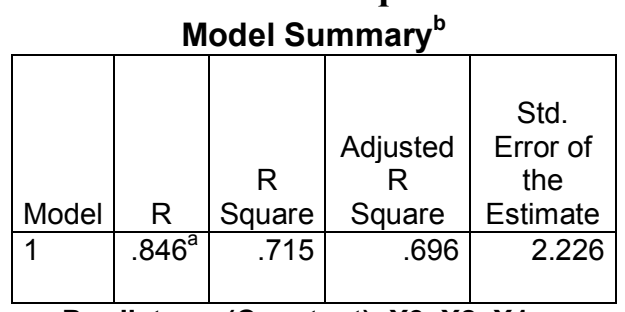

a. Predictors: (Constant), X3, X2, X1

b. Dependent Variable: $Y$

Dari tabel di atas, angka $\mathrm{R}$ sebesar 0,846 menunjukkan bahwa korelasi atau hubungan yang kuat antara variabel independen (luas lahan, tenaga kerja, dan modal) dengan variabel dependen (pendapatan). Koefisien Determinasi (R square) sebesar 0,715 . Nilai 0,715 menunjukkan bahwa variabel pendapatan (Y) dapat dijelaskan oleh variabel luas lahan (X1), tenaga kerja
(X2), dan modal (X3) secara bersama - sama sebesar $71,5 \%$ dan sisanya $28,5 \%$ dipengaruhi oleh faktor lain diluar variabel independen.

\section{Pembahasan Hasil Penelitian \\ Pengaruh Luas Lahan Terhadap Pendapatan (Y)}

(X1)

Luas lahan yang dimiliki oleh petani jagung berbeda - beda. Dengan luas lahan usahatani yang sempit, itu akan membatasi petani untuk meningkatkan pendapatannya, hal tersebut disebabkan karena luas lahan yang sempit dengan kualitas tanah yang kurang baik akan menjadi beban bagi petani pengelola usahatani.

Dengan adanya pengaruh luas lahan terhadap pendapatan petani jagung sebesar 0,426 menyatakan bahwa setiap terjadi penambahan satuan luas lahan akan meningkatkan pendapatan petani jeruk sebesar 0,426 . Semakin luasnya lahan dengan tingkat kesuburan tanah yang bagus akan menghasilkan kualitas jagung yang bagus pula, jadi diperlukan perhatian lebih terhadap pengendalian produktifitas jagung yang akan meningkatkan pendapatan petani jagung. Dengan kata lain luas lahan berpengaruh positif terhadap pendapatan usahatani jagung.

\section{Pengaruh Tenaga Kerja (X2)} Terhadap Pendapatan (Y)

Tenaga kerja merupakan salah satu faktor produksi yang penting dalam usahatani karena setiap usaha pertanian yang dikelola pasti menggunakan tenaga kerja, dan tenaga kerja mempunyai pengaruh yang besar dalam keberhasilan proses produksi.

Berdasarkan hasil penelitian didapat pengaruh tenaga kerja terhadap pendapatan usahatani jagung 
sebesar 0,142, maka setiap terjadi penambahan satuan tenaga kerja akan mempengaruhi pendapatan sebesar 0,142 . Dengan kata lain luas lahan berpengaruh positif terhadap pendapatan usahatani jagung.

\section{Pengaruh Modal (X3) Terhadap Pendapatan (Y)}

Modal sangat diperlukan dalam suatu kegiatan produksi. Dalam usahatani, modal memiliki peran yang besar dalam pengadaan sarana produksi maupun masukan produksi. Kekurangan modal menyebabkan kurangnya masukan yang diberikan sehingga menimbulkan resiko kegagalan atau rendahnya produktifitas. Dengan modal yang cukup maka petani dapat memaksimalkan input dalam usahataninya seperti pembelian bibit dan pupuk yang bermutu dan dapat membayar upah tenaga kerja.

Berdasarkan hasil penelitian didapat pengaruh tenaga kerja terhadap pendapatan usahatani jagung sebesar 0,460, maka setiap terjadi penambahan satuan modal akan mempengaruhi pendapatan sebesar 0,460 . Dengan kata lain modal berpengaruh positif terhadap pendapatan usahatani jagung.

Seperti yang dijelaskan pada poin sebelumnya bahwa faktor yang paling signifikan mempengaruhi pendapatan petani yaitu semakin luasnya lahan akan meningkatkan pendapatan petani jagung. Jadi dapat disimpulkan bahwa diperlukan modal yang lebih untuk membiayai hal - hal tersebut di atas yang berguna untuk meningkatkan pendapatan petani jagung.

Berdasarkan hasil penelitian terbukti bahwa luas lahan, tenaga kerja, dan modal bersama - sama mempunyai hubungan dan pengaruh yang positif terhadap pendapatan petani jagung dengan Koefisien Determinasi $0,715 \quad(71,5 \%)$ dan sisanya sebesar $28,5 \%$ dijelaskan oleh faktor lain diluar analisa variabel dalam penelitian ini. Selain itu, tanda positif 0,715 menunjukkan adanya arah yang sama dari ketiga variabel tersebut, artinya semakin tinggi tingkat variabel $\mathrm{X}$ yang terjadi maka pendapatan petani jagung akan meningkat.

Dari hasil penelitian di atas membuktikan bahwa hipotesis diterima dengan probabilitas 5\%. Dari hasil penelitian dengan pengujian statistik (Uji t) diperoleh bahwa X1 $(0,426), X 2(0,142)$, dan X3 $(0,460)$ dengan $\mathrm{p}<0,05$, yang artinya bahwa luas lahan, tenaga kerja, dan modal memiliki pengaruh yang positif dan signifikan secara parsial terhadap pendapatan petani jagung. Dan dengan Uji F/Anova diperoleh nilai $\mathrm{F}$ $=38.455$ dengan probability $(0,00<0,05)$, hal ini menunjukkan bahwa variabel luas lahan, tenaga kerja, dan modal memiliki pengaruh yang positif dan signifikan secara bersama - sama (simultan) terhadap pendapatan petani jagung di Desa Tupak Raja Kecamatan Gunung Sitember Kabupaten Dairi.

\section{PENUTUP}

Berdasarkan hasil dan pembahasan penelitian, maka penulis membuat beberapa kesimpulan sebagai berikut :

1. Faktor produksi Luas Lahan secara parsial berpengaruh positif dan signifikan terhadap pendapatan petani jagung di Desa Tupak Raja Kecamatan Gunung Sitember Kabupaten Dairi dengan koefisien regresi 
sebesar 0,426. Hal ini menunjukkan jika luas lahan bertambah satu Ha, maka akan meningkatkan pendapatan petani jagung sebesar 0,426.

2. Faktor produksi Tenaga Kerja secara parsial berpengaruh positif dan signifikan terhadap pendapatan petani jagung di Desa Tupak Raja Kecamatan Gunung Sitember Kabupaten Dairi dengan koefisien regresi sebesar 0,142. Hal ini menunjukkan jika terjadi penambahan tenaga kerja, maka akan meningkatkan pendapatan petani jagung sebesar 0,142 .

3. Faktor produksi Modal secara parsial berpengaruh positif dan signifikan terhadap pendapatan petani jagung di Desa Tupak Raja Kecamatan Gunung Sitember Kabupaten Dairi dengan koefisien regresi sebesar 0,460. Hal ini menunjukkan jika terjadi penambahan modal, maka akan meningkatkan pendapatan petani jagung sebesar 0,460 .

4. Faktor - faktor produksi Luas Lahan, Tenaga Kerja, dan Modal secara bersama - sama (simultan) berepengaruh positif dan signifikan terhadap pendapatan petani jagung di Desa Tupak Raja Kecamatan Gunung Sitember Kabupaten Dairi dengan Koefisien Determinasi sebesar 71,5\% dan sisanya $28,5 \%$ dipengaruhi variabel lain diluar penelitian, seperti faktor pelatihan, pengalaman, pendidikan, dan lain sebagainya. Dalam penelitian ini, variabel Modal (X3) lebih besar dibandingkan dengan Luas Lahan (X1) dan Tenaga Kerja (X2), sehingga Modal lebih berpengaruh dalam meningkatkan pendapatan petani jagung. Maka petani harus memperhatikan faktor yang lebih dominan untuk dapat meningkatkan pendapatan.

\section{DAFTAR PUSTAKA}

Adi Budiono, Kamilah Wilda, Meri Dewi Yanti. 2012. Analisis Faktor - faktor yang Mempengaruhi Produksi Jagung di Kecamatan Batu Ampar, Kabupaten Tanah Laut.. Jurnal Agribisnis Pedesaan Vol. 02 No. 02 Juni 2012, Halaman 159 - 171.

Azri Antika, Fani. 2013. "Faktorfaktor yang Mempengaruhi Pendapatan Petani Kacang Tanah di Desa Sawah Tangah Kecamatan Pariangan Kabupaten Tanah Datar (Sumatera Barat)". Universitas Negeri Medan. Skripsi.

Cristoporus dan Sulaeman. 2009. Analisis Produksi dan Pemasaran Jagung di Desa Labuan Toposo Kecamatan Tawaeli, Kabupaten Donggala. Jurnal Agroland 16 (2) : Juni 2009, Halaman 141 $-147$.

Habibi, Jamin. 2008. Studi Pengaruh Biaya Produksi dan Harga Jual Terhadap Pendapatan Petani Cabe Merah di Desa Serubeba Kecamatan Rote Timur Kabupaten Rote Ndao. 
Jurnalitbangda. Volume IV, Nomor 3, Halaman 217 - 228. Hernanto, Fadholi. 2001. Ilmu Usahatani. Penebar Swadaya : Jakarta.

Husodo, Sapto, dkk. 2004. Jurnal Ilmu - Ilmu Pertanian. STTP : Yogyakarta.

Isnala Rido, Kami. 2010. "Pengaruh Faktor-faktor Produksi terhadap Pendapatan Usaha Tani Jagung di Kecamatan Tiga Binanga Kabupaten Karo". Universitas Negeri Medan. Skripsi.

Irving Clark Kaiya Putri. 2013. Analisis Pendapatan Petani Kakao di Kabupaten Parigi Moutong. Jurnal EMBA. Vol. 1 No. 4. Desember 2013, Halaman 2195 - 2205.

Kuncoro, Mudrajad. 2009. Metode Riset untuk Bisnis dan Ekonomi. Penerbit Erlangga : PT. Gelora Aksara Pratama.

Mahdiah. 2010. Analisis Pengaruh

Penggunaan Faktor Produksi Usahatani Jagung (Zea mays $L)$.

http://jurnalagribisnis.co.id/ Wacana Vol. 13 No. 14. Oktober $2010: 684-688$.

Purnomo, M, S dan Hartono. 2003. Bertanam Jagung Unggul. Penebar Swadaya: Jakarta.

Rahmita, Budiartiningsih, Yusni Maulida, dan Taryono. 2010. Faktor - Faktor yang Mempengaruhi Peningkatan Pendapatan Petani Melalui Sektor Informal di Desa Kedaburapat Kecamatan Rangsang Barat Kabupaten
Bengkalis. Jurnal Ekonomi. Volume 18, Nomor 1. Maret 2010. Halaman 79 - 93.

Ribut Santoso, Hari Sudarmadji, Awiyanto. 2013. Faktor faktor yang Mempengaruhi Produksi Jagung di Kabupaten Sumenep. http://jurnalagribisnis.co.id/ Vol. 10 No. 1. Nopember $2013: 10-17$.

Riduwan, Akdon. 2007. Rumus dan Data Dalam Analisis Statistik Untuk Penelitian. Alfabeta : Bandung.

Rustam. 2002. Refleksi 4 Tahun Reformasi Inti Sari Loka Karya Nasional Sosial. Foresty : Bandung.

Soekartawi. 2001. Agribisnis Teori dan Aplikasinya. PT. Raja Grafindo Persada : Jakarta. Brawijaya : Jakarta.

Sugiyono. 2012. Metode Penelitian Bisnis. Cetakan ke-16. Bandung: Alfabeta.

Sujarno. 2008. Analisis Faktor Faktor yang Mempengaruhi Pendapatan Nelayan di Kabupaten Langkat. Tesis Pascasarjana USU.

Suratiyah. 2002. Ilmu Usahatani. Penebar Swadaya : Jakarta.

Tohir, K, A. 2001. Seuntai Pengetahuan Usaha Tani Indonesia. Rineka Cipta: Jakarta.

Yulianto, Eko Harri. 2005. Pengaruh Biaya Saprodi dan Tenaga Kerja Terhadap Pendapatan Usahatani Semangka. Jurnal EPP. Volume 2, Nomor 2, Halaman $24-32$. 